\title{
PENGARUH PENAMBAHAN TEPUNG TERIGU TERHADAP MUTU BAKSO JAMUR TIRAM PUTIH
}

\author{
Mohamad Yogi Hertanto \\ Aisyah Larasati \\ Issutarti
}

\begin{abstract}
Abstrak: Tujuan penelitian untuk menganalisis kandungan proksimat dan sifat organoleptik bakso jamur tiram. Penelitian eksperimen ini menggunakan Rancangan Acak Lengkap (RAL) dengan dua kali pengulangan. Data kandungan proksimat dianalisis menggunakan ANOVA dilanjutkan dengan uji DMRT. Hasil penelitian menunjukan bahwa kandungan proksimat bakso jamur tiram dengan penambahan tepung terigu meliputi protein, lemak, air, abu, serat kasar, dan serat kasar secara berurutan untuk perlakuan $1 \%$ yaitu $11,64 \%, 4,03 \%, 46,73 \%, 5,31 \%, 1,55 \%$ dan $28,51 \%$, untuk perlakuan $2 \%$ yaitu $12,53 \%, 3,29 \%, 48,75 \%, 5,59 \%, 1,86 \%$, dan $29,84 \%$ dan untuk perlakuan $3 \%$ yaitu $13,18 \%, 2,86 \%, 49,79 \%, 5,66 \%, 2,20 \%$ dan 32,28\%. Penambahan tepung berpengaruh terhadap tekstur dan rasa. Hasil skor tekstur 4,33 (cukup kenyal) dan skor rasa 4,17 (cukup sedap). Penambahan tepung terigu berpengaruh terhadap tekstur, dengan hasil skor 4,16 (agak suka). Kesimpulan dari penelitian ini adalah kadar abu bakso jamur tiram masih belum memenuhi syarat SNI bakso 2014.
\end{abstract}

Kata-kata Kunci: bakso, jamur tiram putih, tepung terigu, uji proksimat

\begin{abstract}
The Effect of Wheat Flour Addition on the Quality of Oyster Mushrooms Meatball. This research aims to analyze the proximate content and organoleptic properties of oyster mushroom meatballs. The experimental research used a Completely Randomized Design with two replications. The proximate content data was analyzed using One Way ANOVA and followed by DMRT test. The results showed the proximate content of the oyster mushroom meatball with the addition of wheat flour which included protein, fat, water, ash, crude fiber and carbohydrate subsequently for $1 \%$ treatment was $11.64 \%, 4.03 \%, 46.73 \%, 5.31 \%, 1.55 \%$, and $28.51 \%$. The contents for $2 \%$ treatment was $12.53 \%, .29 \%, 48.75 \%, 5.59 \%, 1.86 \%$, and $29.84 \%$, and the contents for $3 \%$ treatment was $13.18 \%, 2.86 \%, 49.79 \%, 5.66 \%, 2.20 \%$, and $32.28 \%$. The addition of wheat flour affected the texture of the meatball with the score of 4.33 (quite chewy) and taste of the meat ballwith the score of 4.16 (quite hedonic). The research concluded that the ash content of the oyster mushroom meatballs does not fulfill the requirement of the Indonesian National Standard of Meatball published in year 2014.
\end{abstract}

Keywords: meatballs, oyster mushroom, wheat flour, proximate test

I ndonesia mempunyai berbagai macam jenis jamur yang dapat dikonsumsi oleh masyarakat. Salah satu jenis jamur yang mudah untuk dibudidayakan adalah jamur tiram (Pleurotus ostreatus). Jamur tiram merupakan sumber makanan

Mohammad Yogi Hertanto adalah Mahasiswa Jurusan Teknologi Industri Universitas Negeri Malang. Email: Hertanto.yogi@gmail.com. Aisyah Larasati dan Issutarti adalah Dosen Teknologi Industri Universitas Negeri Malang. Alamat Kampus: Jl. Semarang No. 5 Malang 65145. 
alternatif yang setara dengan daging dan ikan karena bergizi tinggi. Jamur tiram adalah salah satu jamur yang mempunyai kandungan gizi yang tinggi.

Kandungan gizi jamur tiram per 100 g yaitu protein 10,5-30,4\% (Sumarmi, 2006). Sementara masyarakat yang mengkonsumsi jamur tiram masih sedikit. Hal ini disebabkan karena olahan jamur tiram yang dikenal masyarakat masih sedikit.

Jamur tiram yang harganya murah dapat digunakan sebagai bahan pangan yang memberikan asupan protein yang tinggi. Jamur tiram dapat dijadikan sebagai bahan pengganti olahan daging seperti bakso, burger, nugget, sosis dan abon. Salah satu produk olahan daging yang banyak disukai oleh seluruh masyarakat yaitu bakso.

Bakso merupakan makanan yang terbuat dari daging. Pemilihan jamur tiram mempunyai tekstur yang kenyal dan berserat hampir menyerupai daging inilah kelebihan paling penting untuk membuat makanan olahan. Pengolahan jamur secara benar menjadikan rasa jamur mirip dengan daging sapi (Anwar, 2012:5). Walaupun kandungan protein jamur tiram dan daging hampir sama, tetapi kedua bahan ini tetap berbeda.

Penambahan tepung terigu bertujuan untuk memperbaiki elastisitas dari produk dan berfungsi untuk menarik air, memberikan warna dan membentuk tekstur yang padat akan tetapi tepung terigu dapat menurunkan rasa pada produk akhir (Pasaribu, 2009).

\section{METODE}

Penelitian yang dilakukan merupakan penelitian eksperimen. Rancangan penelitian menggunakan Rancangan Acak Lengkap (RAL) dengan satu perlakuan yaitu penggunaan tepung terigu dengan rasio $1 \%, 2 \%$, dan $3 \%$ dari total jamur tiram dan masing-masing perlaku- an diulang sebanyak dua kali, kemudian penelitian ini juga mencangkup uji kimia (Kadar abu, kadar air, protein, lemak, karbohidrat, dan serat kasar) dan uji mutu organoleptik.

Bahan-bahan yang digunakan dalam pembuatan bakso jamur tiram putih adalah jamur tiram putih, tepung tapioka, garam, merica, bawang putih dan putih telur.

Alat yang digunakan dalam proses pembuatan bakso jamur tiram adalah timbangan digital, baskom, pisau, kain saring, talenan, sendok, panci, kompor, penyaring santan.

Pengamatan yang dilakukan pada bakso jamur tiram meliputi analisis kimia, uji mutu hedonik dan uji hedonik terhadap bakso jamur tiram.

\section{HASIL}

Hasil Analisis Kimia Bakso Jamur Tiram Putih sebagai berikut.

\section{Kadar Protein}

Kadar protein bakso jamur tiram yang diperoleh sebesar 11,65-13,18\%. Hasil rerata kadar protein dapat dilihat pada Tabel 1.

Berdasarkan hasil yang ditujukan pada tabel kadar protein tertinggi diperoleh dari bakso jamur tiram dengan penambahan tepung terigu 3\% sedangkan kadar protein terendah diperoleh dari bakso jamur tiram dengan penambahan $1 \%$.

\section{Kadar Lemak}

Kadar lemak bakso jamur tiram yang diperoleh sebesar 2,86-4,03\%. Hasil rerata kadar lemak dapat dilihat pada Tabel 2.

Berdasarkan hasil yang ditujukan pada tabel kadar lemak tertinggi diperoleh dari penambahan tepung terigu $1 \%$, sedangkan kadar lemak terendah di peroleh dari penambahan tepung terigu $3 \%$. 
Tabel 1. Rerata Kadar Protein Bakso Jamur Tiram Putih dengan Penambahan Tepung Terigu

\begin{tabular}{lccc}
\hline Sampel & Pengulangan & $\begin{array}{c}\text { Protein } \\
(\boldsymbol{\%})\end{array}$ & $\begin{array}{c}\text { Rerata } \\
(\boldsymbol{\%})\end{array}$ \\
\hline P1 & 1 & 11,548 & 11,648 \\
& 2 & 11,749 & \\
P2 & 1 & 12,600 & 12,526 \\
& 2 & 12,451 & \\
P3 & 1 & 13,305 & 13,183 \\
& 2 & 13,061 & \\
\hline
\end{tabular}

Tabel 2. Rerata Kadar Lemak Bakso Jamur Tiram Putih dengan Penambaha Tepung Terigu

\begin{tabular}{lccc}
\hline Sampel Pengulangan & $\begin{array}{c}\text { Lemak } \\
(\boldsymbol{\%})\end{array}$ & $\begin{array}{c}\text { Rerata } \\
(\mathbf{\%})\end{array}$ \\
\hline \multirow{2}{*}{ P1 } & 1 & 4,074 & 4,03 \\
& 2 & 3,982 & \\
P2 & 1 & 3,332 & \\
& 2 & 3,244 & 3,29 \\
P3 & 1 & 2,883 & \\
& 2 & 2,843 & 2,86 \\
\hline
\end{tabular}

Tabel 3. Rerata Kadar Air Bakso Jamur Tiram Putih dengan Penambahan Tepung Terigu

\begin{tabular}{cccc}
\hline Sampel Pengulangan & $\begin{array}{c}\text { Air } \\
(\boldsymbol{\%})\end{array}$ & $\begin{array}{c}\text { Rerata } \\
(\boldsymbol{\%})\end{array}$ \\
\hline P1 & 1 & 46,690 & \\
& 2 & 46,777 & 46,73 \\
P2 & 1 & 48,776 & \\
& 2 & 48,727 & 48,75 \\
P3 & 1 & 49,950 & \\
& 2 & 49,628 & 49,79 \\
\hline
\end{tabular}

Tabel 4. Rerata Kadar Abu Bakso Jamur Tiram Putih dengan Penambahan Tepung Terigu

\begin{tabular}{lccc}
\hline Sampel & Pengulangan & $\begin{array}{c}\text { Abu } \\
(\boldsymbol{\%})\end{array}$ & $\begin{array}{c}\text { Rerata } \\
(\boldsymbol{\%})\end{array}$ \\
\hline P1 & 1 & 5,276 & \\
& 2 & 5,347 & 5,31 \\
P2 & 1 & 5,597 & \\
& 2 & 5,592 & 5,59 \\
P3 & 1 & 5,655 & \\
& 2 & 5,658 & 5,66 \\
\hline
\end{tabular}

3. Kadar Air

Kadar air bakso jamur tiram yang diperoleh sebesar 46,73-49,79\%. Hasil rerata kadar lemak dapat dilihat pada Tabel 3.

Berdasarkan hasil yang ditujukan pada tabel kadar air tertinggi diperoleh dari penambahan tepung terigu 3\%, sedangkan kadar lemak terendah di peroleh dari penambahan tepung terigu $1 \%$.

4. Kadar Abu

Kadar abu bakso jamur tiram yang diperoleh sebesar 5,31-5,66\%. Hasil rerata kadar abu dapat dilihat pada tabel 4

Berdasarkan hasil yang ditujukan pada tabel kadar abu dengan bakso jamur tiram dengan penambahan tepung terigu $1 \%$ dari total jamur tiram berbeda dan lebih rendah dari formula lainnya. Kadar abu formula bakso jamur tiram dengan penambahan tepung terigu $2 \%$ dari total jamur tiram tidak berbeda dengan formula bakso jamur tiram dengan penambahan

Tabel 5. Rerata Serat Kasar Bakso Jamur Tiram dengan Penambahan Tepung Terigu

\begin{tabular}{lccc}
\hline Sampel & Pengulangan & $\begin{array}{c}\text { Serat } \\
\text { kasar }(\%)\end{array}$ & $\begin{array}{c}\text { Rerata } \\
(\boldsymbol{\%})\end{array}$ \\
\hline P1 & 1 & 1,545 & \\
& 2 & 1,546 & 1,55 \\
P2 & 1 & 1,935 & \\
& 2 & 1,790 & 1,86 \\
P3 & 1 & 2,145 & \\
& 2 & 2,248 & 2,20 \\
\hline
\end{tabular}

Tabel 6. Rerata Karbohidrat bakso Jamur Tiram Putih dengan Penambahan Tepung Terigu

\begin{tabular}{lccc}
\hline Sampel & Pengulangan & $\begin{array}{c}\text { Karbo- } \\
\text { hidrat } \\
(\boldsymbol{\%})\end{array}$ & $\begin{array}{c}\text { Rerata } \\
(\boldsymbol{\%})\end{array}$ \\
\hline P1 & 1 & 32,412 & \\
& 2 & 32,145 & 28,51 \\
P2 & 1 & 29,695 & \\
& 2 & 29,987 & 29,84 \\
P3 & 1 & 28,207 & \\
& 2 & 28,811 & 32,28 \\
\hline
\end{tabular}




\section{Serat Kasar}

Serat kasar bakso jamur tiram yang diperoleh sebesar 1,55-2,20\%. Hasil rerata serat kasar dapat dilihat pada Tabel 5.

Berdasarkan hasil yang ditujukan pada tabel serat kasar tertinggi diperoleh dari penambahan tepung terigu 3\%, sedangkan serat kasar terendah di peroleh dari penambahan tepung terigu $1 \%$.

6. Karbohidrat

Karbohidrat bakso jamur tiram yang diperoleh sebesar 28,51-32,28\%. Hasil rerata karbohidrat pada bakso jamur tiram dapat diliat pada Tabel 6 .

Berdasarkan hasil yang ditujukan pada tabel karbohidrat tertinggi diperoleh dari penambahan tepung terigu $1 \%$, sedangkan karbohidrat terendah di peroleh dari penambahan tepung terigu $3 \%$.

Hasil uji mutu hedonik bakso jamur tiram dengan penambahan tepung terigu sebagai berikut.

\section{Uji Mutu Hedonik Aroma}

Hasil rerata uji mutu hedonik warna bakso jamur tiram dengan penambaha tepung terigu dapat dilihat pada Gambar 1.

Hasil ANOVA uji hedonik aroma bakso jamur tiram putih dengan penambahan tepung terigu dapat diartkan tidak ada perbedaan yang nyata terhadap mutu hedonik aroma bakso jamur tiram.

2. Uji Mutu Hedonik Tekstur

Hasil rerata uji mutu hedonik tekstur bakso jamur tiram dengan penambahan tepung terigu dapat dilihat pada Gambar 2.

Uji mutu hedonik tekstur bakso jamur tiram dengan penambahan tepung terigu $1 \%$ dari total jamur tiram tidak berbeda dengan penambahan tepung terigu $2 \%$. Bakso jamur tiram dengan penambahan tepung terigu $2 \%$ dari total jamur tiram tidak berbeda dengan penambahan tepung terigu 3\%. Bakso jamur tiram dengan penambahan tepung terigu $1 \%$ dari total jamur tiram berbeda dengan penambahan tepung terigu $3 \%$ dari total jamur.

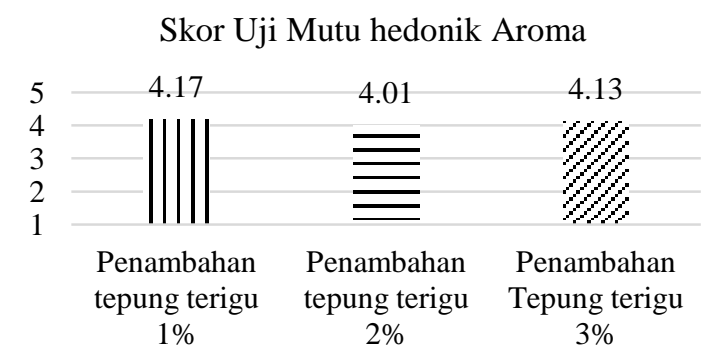

Gambar 1. Hasil Rerata Uji Mutu Hedonik Aroma Bakso Jamur Tiram dengan Penambahan Tepung Terigu

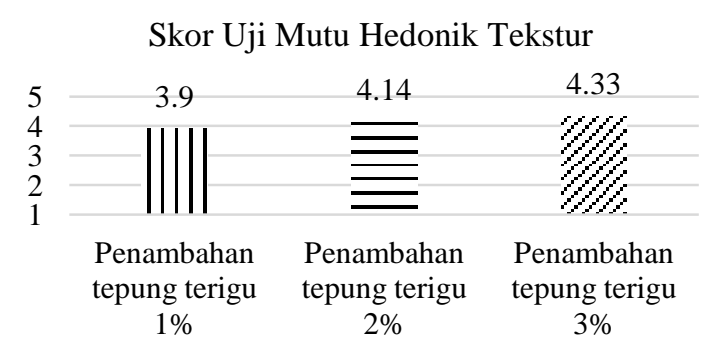

Gambar 2. Hasil Rerata Uji Mutu Hedonik Tekstur Bakso Jamur Tiram dengan Penambahan Tepung Terigu

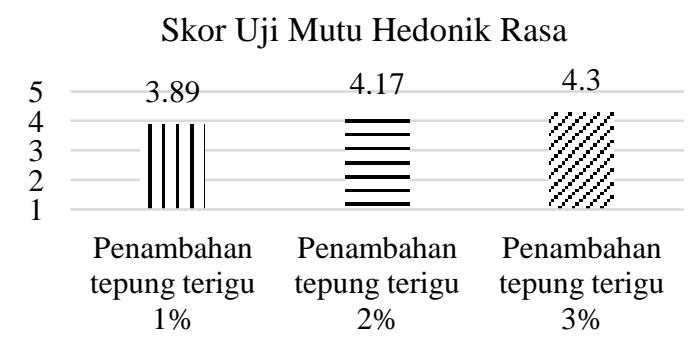

Gambar 3. Hasil Rerata Uji Mutu Hedonik Rasa Bakso Jamur Tiram dengan Penambahan Tepung Terigu

3. Uji Mutu Hedonik Rasa

Hasil rerata uji mutu hedonik rasa bakso jamur tiram dengan penambahan tepung terigu dapat dilihat pada Gambar 3.

Uji mutu hedonik rasa bakso jamur tiram dengan penambahan tepung terigu $1 \%$ dari total jamur tiram berbeda dan lebih rendah dibandingkan dengan 
Skor Uji Hedonik Aroma

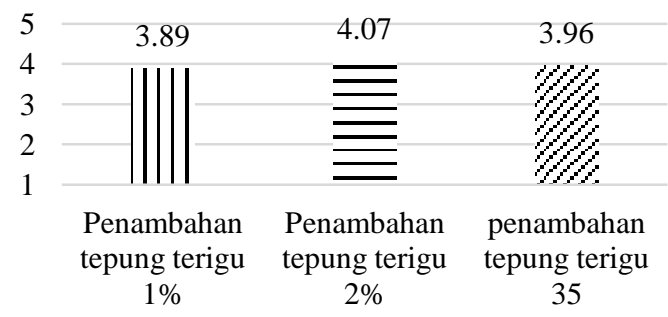

Gambar 4. Hasil Rerata Uji Hedonik Aroma Bakso Jamur Tiram dengan Penambahan Tepung Terigu

Skor Uji Hedonik Tekstur

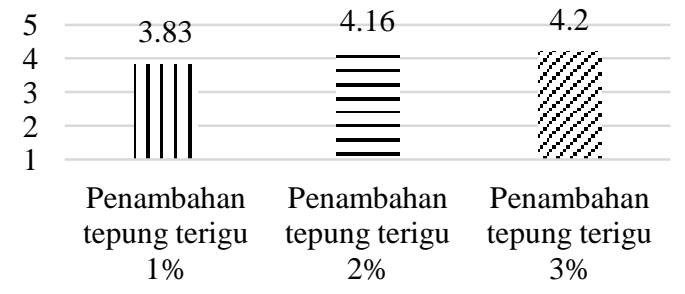

Gambar 5. Hasil Rerata Uji Hedonik Aroma Bakso Jamur Tiram dengan Penambahan Tepung Terigu

Skor Uji Hedonik Rasa

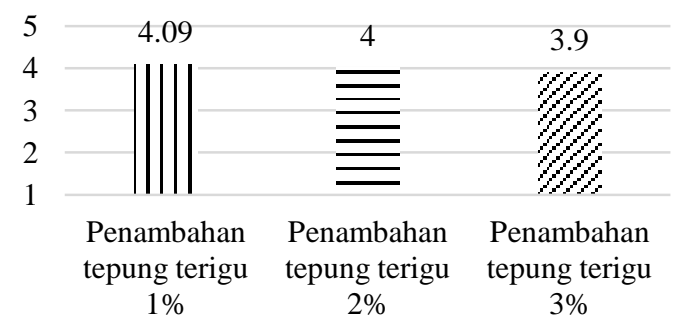

Gambar 6. Hasil Rerata Uji Hedonik Aroma Bakso Jamur Tiram dengan Penambahan Tepung Terigu

formulasi lainnya. Bakso jamur tiram dengan penambahan $2 \%$ tidak berbeda dengan penambahan tepung terigu $3 \%$ dari total jamur tiram.

Hasil uji hedonik (kesukaan) bakso jamur tiram dengan penambahan tepung terigu sebagai berikut.

1. Uji Hedonik (kesukaan) Aroma

Hasil rerata uji hedonik aroma bakso jamur tiram dengan penambahan tepung terigu dapat dilihat pada Gambar 4.
Hasil ANOVA uji hedonik aroma bakso jamur tiram dengan penambahan tepung terigu dapat diartikan tidak ada perbedaan yang nyata pada aroma bakso jamur tiram dengan penambahan tepung terigu dari total jamur tiram putih.

2. Uji Hedonik Tekstur

Hasil rerata uji hedonik aroma bakso jamur tiram dengan penambahan tepung terigu dapat dilihat pada Gambar 5.

Tekstur bakso jamur tiram dengan formulasi penambahan tepung terigu $1 \%$ dari total jamur tiram berbeda dan lebih rendah dibandingkan dengan formulasi lainnya. Bakso jamur tiram dengan formulasi penamabahan tepung terigu $2 \%$ dari total jamur tiram tidak berbeda dengan formulasi bakso jamur tiram penambahan tepung terigu 3\% dari total jamur tiram.

3. Uji Hedonik Rasa

Hasil analisis uji hedonik rasa bakso jamur tiram dengan penambahan tepung terigu dapat dilihat pada Gambar 6 .

Hasil ANOVA uji hedonik rasa bakso jamur tiram dengan penambahan teung terigu dapat diartikan tidak ada perbedaan yang nyata terhadap rasa bakso jamur tiram.

\section{PEMBAHASAN}

Pembahasan uji kimia bakso jamur tiram sebagai berikut.

1. Kadar Protein

Perlakuan formulasi yang berbeda yaitu formulasi bakso jamur tiram dengan penambahan tepung terigu $1 \%(\mathrm{P} 1)$, bakso jamur dengan penambahan tepung terigu 2\% (P2), dan bakso jamur tiram dengan penambahan tepung terigu 3\% (P3) menunjukkan hasil yang berbeda nyata.

Perbedaan kandungan kadar protein pada bakso jamur tiram merupakan pengaruh dari tepung terigu. Semakin banyak tepung terigu yang ditambahkan, kadar protein pada bakso jamur semakin tinggi. Sebaliknya, pengurangan jamur tiram 
pada formulasi bakso mengakibatkan kadar protein semakin menurun.

Kadar protein bakso jamur tiram dengan penambahan tepung terigu dari total jamur tiram formula bakso jamur dengan penambahan tepung terigu $1 \%$ sebesar 11,648 , formula bakso dengan penambahan tepung terigu $2 \%$ sebesar 12,526 , dan formula bakso dengan penambahan tepung terigu $3 \%$ sebesar 13,183. Bakso jamur tiram dengan penambahan tepung terigu tersebut telah memenuhi syarat Standar Nasional Indonesia Bakso daging dengan kandungan minimal protein $11 \%$.

Hasil analisis menunjukan kadar protein tertinggi diperoleh dari bakso jamur tiram dengan penambahan tepung terigu 3\% sedangkan kadar protein terendah diperoleh dari bakso jamur tiram dengan penambahan tepung terigu $1 \%$.

\section{Kadar Lemak}

Perlakuan formulasi yang berbeda yaitu formulasi bakso jamur tiram dengan penambahan tepung terigu $1 \%(\mathrm{P} 1)$, bakso jamur dengan penambahan tepung terigu $2 \%(\mathrm{P} 2)$, dan bakso jamur tiram dengan penambahan tepung terigu 3\% (P3) menunjukkan hasil yang berbeda nyata.

Perbedaan kandungan kadar lemak pada bakso jamur tiram merupakan pengaruh dari tepung terigu. Semakin banyak tepung terigu yang ditambahkan, kadar lemak pada bakso jamur semakin menurun. Sebaliknya, pengurangan jamur tiram pada formulasi bakso mengakibatkan kadar lemak semakin tinggi.

Kadar lemak bakso jamur tiram dengan penambahan tepung terigu $1 \%$ dari total jamur tiram sebesar $4,03 \%$, formula bakso jamur tiram dengan penambahan tepung terigu $2 \%$ sebesar $3,29 \%$, dan formula bakso jamur tiram dengan penambahan tepung terigu 3\% sebesar 2,86\%.

Bakso jamur tiram dengan penambahan tepung terigu dari total jamur tiram tersebut telah memenuhi syarat Standar Nasional Indonesia bakso daging dengan kandungan maksimal lemak 10\%.
Hasil analisis menunujukan kadar lemak tertinggi diperoleh dari penambahan tepung terigu $1 \%$, sedangkan kadar lemak terendah di peroleh dari penambahan tepung terigu $3 \%$.

\section{Kadar Air}

Perlakuan formulasi yang berbeda yaitu formulasi bakso jamur tiram dengan penambahan tepung terigu $1 \%(\mathrm{P} 1)$, bakso jamur dengan penambahan tepung terigu $2 \%(\mathrm{P} 2)$, dan bakso jamur tiram dengan penambahan tepung terigu 3\% (P3) menunjukkan hasil yang berbeda nyata.

Perbedaan kandungan kadar air pada bakso jamur tiram merupakan pengaruh dari tepung terigu. Semakin banyak tepung terigu yang ditambahkan, kadar air pada bakso jamur semakin tinggi. Sebaliknya, pengurangan jamur tiram pada formulasi bakso mengakibatkan kadar protein semakin menurun.

Kadar air bakso jamur tiram dengan penambahan tepung terigu $1 \%$ dari total jamur tiram sebesar $46,73 \%$, formula bakso jamur tiram dengan penambahan tepung terigu $2 \%$ sebesar $48,75 \%$, dan formula bakso jamur tiram dengan penambahan tepung terigu $3 \%$ sebesar $49,79 \%$. Bakso jamur tiram dengan penambahan tepung terigu dari total jamur tiram tersebut telah memenuhi syarat Standar Nasional Indonesia bakso daging dengan kandungan maksimal air 70\%.

Hasil analisis menunjukan kadar air tertinggi diperoleh dari penambahan tepung terigu 3\%, sedangkan kadar lemak terendah di peroleh dari penambahan tepung terigu $1 \%$.

\section{Kadar Abu}

Perlakuan formulasi yang berbeda yaitu formulasi bakso jamur tiram dengan penambahan tepung terigu $1 \%(\mathrm{P} 1)$, bakso jamur dengan penambahan tepung terigu $2 \%(\mathrm{P} 2)$, dan bakso jamur tiram dengan penambahan tepung terigu $3 \%$ (P3) menunjukkan hasil yang berbeda nyata. 
Perbedaan kandungan kadar abu pada bakso jamur tiram merupakan pengaruh dari tepung terigu. Semakin banyak tepung terigu yang ditambah kan, kadar abu pada bakso jamur semakin tinggi. Sebaliknya, pengurangan jamur tiram pada formulasi bakso mengakibatkan kadar protein semakin menurun.

Kadar abu bakso jamur tiram dengan penambahan tepung terigu $1 \%$ dari total jamur tiram sebesar $5,31 \%$, formula bakso jamur tiram dengan penambahan tepung terigu $2 \%$ sebesar $5,59 \%$, dan formula bakso jamur tiram dengan penambahan tepung terigu 3\% sebesar 5,66\%. Bakso jamur tiram dengan penambahan tepung terigu dari total jamur tiram tersebut tidak memenuhi syarat Standar Nasional Indonesia bakso daging dengan kandungan maksimal abu 3,0\%.

Hasil analisis menunujukan kadar abu dengan bakso jamur tiram dengan penambahan tepung terigu $1 \%$ dari total jamur tiram berbeda dan lebih rendah dari formula lainnya. Kadar abu formula bakso jamur tiram dengan penambahan tepung terigu $2 \%$ dari total jamur tiram tidak berbeda dengan formula bakso jamur tiram dengan penambahan tepung terigu 3\% dari total jamut tiram.

\section{Serat Kasar}

Perlakuan formulasi yang berbeda yaitu formulasi bakso jamur tiram dengan penambahan tepung terigu $1 \%(\mathrm{P} 1)$, bakso jamur dengan penambahan tepung terigu $2 \%(\mathrm{P} 2)$, dan bakso jamur tiram dengan penambahan tepung terigu 3\% (P3) menunjukkan hasil yang berbeda nyata.

Perbedaan kandungan serat kasar pada bakso jamur tiram merupakan pengaruh dari tepung terigu. Semakin banyak tepung terigu yang ditambahkan, serat kasar pada bakso jamur semakin tinggi. Sebaliknya, pengurangan jamur tiram pada formulasi bakso mengakibatkan kadar protein semakin menurun.

Serat kasar bakso jamur tiram dengan penambahan tepung terigu $1 \%$ dari total jamur tiram sebesar $1,55 \%$, formula bakso jamur tiram dengan penambahan tepung terigu $2 \%$ sebesar $1,86 \%$, dan formula bakso jamur tiram dengan penambahan tepung terigu 3\% sebesar 2,20\%.

Hasil analisis menunujukan serat kasar tertinggi diperoleh dari penambahan tepung terigu $3 \%$, sedangkan serat kasar terendah di peroleh dari penambahan tepung terigu $1 \%$.

6. Karbohidrat

Perlakuan formulasi yang berbeda yaitu formulasi bakso jamur tiram dengan penambahan tepung terigu $1 \%(\mathrm{P} 1)$, bakso jamur dengan penambahan tepung terigu $2 \%(\mathrm{P} 2)$, dan bakso jamur tiram dengan penambahan tepung terigu 3\% (P3) penunjukkan hasil yang berbeda nyata.

Perbedaan kandungan karbohidrat pada bakso jamur tiram merupakan pengaruh dari tepung terigu. Semakin banyak tepung terigu yang ditambahkan, karbohidrat pada bakso jamur semakin tinggi. Sebaliknya, pengurangan jamur tiram pada formulasi bakso mengakibatkan kadar protein semakin menurun.

Karbohidrat bakso jamur tiram dengan penambahan tepung terigu $1 \%$ dari total jamur tiram sebesar $28,51 \%$, formula bakso jamur tiram dengan penambahan tepung terigu $2 \%$ sebesar $29,84 \%$, dan formula bakso jamur tiram dengan penambahan tepung terigu $3 \%$ sebesar $32,28 \%$.

Hasil analisis menunjukan karbohidrat tertinggi diperoleh dari penambahan tepung terigu $1 \%$, sedangkan karbohidrat terendah di peroleh dari penambahan tepung terigu $3 \%$.

Pembahasan uji mutu hedonik bakso jamur tiram putih sebagai berikut.

1. Uji Mutu Hedonik Aroma

Hasil analisis uji mutu hedonik aroma pada bakso jamur tiram dengan penambahan tepung terigu yang berbeda menunjukkan hasil yang tidak berbeda nyata. Aroma bakso jamur tiram yang di hasilkan berkisar antara 4,01\% - 4,37\% 
(aroma jamur cukup kuat). Formulasi bakso jamur tiram dengan penambahan tepung terigu $3 \%$ memiliki skor tertinggi. Hal ini disebabkan penambahan tepung terigu sangat kecil sehingga tidak berpengaruh terhadap aroma bakso jamur tiram.

2. Uji Mutu Hedonik Tekstur

Hasil analisis uji mutu hedonik tekstur pada bakso jamur tiram dengan penambahan tepung terigu yang berbeda menunjukkan hasil yang berbeda nyata. Tekstur bakso jamur tiram yang di hasilkan berkisar antara 3,9\% (bakso kurang kenyal) - 4,33\% (bakso cukup kenyal). Menurut Winarno (1992) dalam Fitasari (2009) penambahan air ke dalam tepung akan menyebabkan pati menyerap air dan membengkak, meskipun jumlah air yang terserap hanya mencapai 30\%. Hal ini dapat menyebabkan semakin tinggi jumlah tepung terigu, semakin kenyal tekstur bakso jamur tiram.

\section{Uji Mutu Hedonik Rasa}

Hasil analisis uji mutu hedonik rasa pada bakso jamur tiram dengan penambahan tepung terigu yang berbeda dapat disimpulkan terdapat perbedaan yang nyata pada uji mutu hedonik rasa bakso jamur tiram putih dengan penambahan tepung terigu berbeda.

Rasa bakso jamur tiram yang di hasilkan berkisar antara 3,89\% (kurang sedap) $-4,30 \%$ (cukup sedap). Semakin banyak penambahan tepung terigu skor rasa bakso jamur cukup sedap. hal ini diduga dalam jamur tiram mengandung asam glutamat yang menimbulkan rasa sedap atau gurih pada makanan (Widyastuti, dkk. 2015). Asam glutamat pada jamur tiram akan hilang kalau direbus, sehingga penambahan tepung terigu dapat mengikat/ menyerap asam glutamat ke dalam tepung terigu waktu perebusan.

Pembahasan uji hedonik bakso jamur tiram putih sebagai berikut.

\section{Uji Hedonik Aroma}

Hasil analisis uji hedonik bakso jamur tiram dengan penambahan tepung terigu yang berbeda menunjukkan hasil yang tidak berbeda nyata. Bakso jamur dengan penambahan tepung terigu $1 \%$ dari total jamur tiram 3,89 (biasa), kemudian skor uji kesukaan bakso jamur tiram dengan penambahan tepung terigu $2 \%$ dari total jamur tiram yaitu 4,07 (agak suka). Skor aroma uji kesukaan bakso jamur tiram putih dengan penambahan tepung terigu $3 \%$ dari total jamur tiram yaitu 3,96 (biasa saja).

\section{Uji Hedonik Tekstur}

Hasil analisis uji hedonik terhadap tekstur bakso jamur tiram dengan penambahan tepung terigu yang berbeda menunjukkan hasil yang berbeda nyata. Skor uji kesukaan dari bakso jamur tiram dengan penambahan tepung terigu $1 \%$ dari total jamur tiram yaitu 3,83 (biasa saja), kemudian skor tekstur uji kesukaan bakso jamur tiram dengan penambahan tepung terigu $2 \%$ yaitu 4,16 (agak suka). Skor warna uji kesukaan bakso jamur tiram dengan penambahan tepung terigu $3 \%$ yaitu 4,20 (agak suka).

Tekstur bakso jamur tiram dengan formulasi penambahan tepung terigu $1 \%$ dari total jamur tiram berbeda dan lebih rendah dibandingkan dengan formulasi lainnya. Bakso jamur tiram dengan formulasi penamabahan tepung terigu $2 \%$ dari total jamur tiram tidak berbeda dengan formulasi bakso jamur tiram penambahan tepung terigu $3 \%$ dari total jamur tiram.

\section{Uji Hedonik Rasa}

Hasil analisi uji hedonik bakso jamur tiram dengan penambahan tepung terigu yang berbeda menunjukkan hasil yang tidak berbeda nyata. Skor uji kesukaan rasa dari bakso jamur tiram putih penambahan tepung terigu $1 \%$ yaitu 4,09 (agak suka), kemudian skor rasa uji kesukaan bakso jamur tiram putih penambahan tepung terigu $2 \%$ yaitu 4 (agak 
suka). Skor rasa uji kesukaan bakso dengan penambahan tepung terigu $3 \%$ yaitu 3,9 (biasa saja).

\section{SIMPULAN DAN SARAN}

Simpulan dari penelitian ini adalah: (1) Kandungan proksimat pada bakso jamur tiram menunjukkan hasil yang berbeda nyata pada kadar protein, kadar lemak, kadar air, kadar abu, serat kasar dan karbohidrat. Hasil kadar protein tertinggi diperoleh dengan penambahan tepung terigu sebesar 3\%, kadar lemak tertinggi pada penambahan $1 \%$, kadar air tertinggi pada penambahan 3\%, kadar abu tertinggi pada penambahan $3 \%$, kadar serat kasar tertinggi pada penambahan $3 \%$, dan kadar karbohidrat tertinggi pada penambahan $1 \%$. (2) Mutu hedonik bakso jamur tiram berbeda nyata untuk rasa dan tekstur, tetapi tidak berbeda nyata untuk aroma. Skor tekstur tertinggi pada penambahan 3\% dan score rasa tertinggi pada penambahan 3\%. (3) Hedonik bakso jamur tiram berbeda nyata untuk aroma dan rasa, tetapi tidak berbeda nyata untuk tekstur. Skor tekstur tertinggi pada penambahan $2 \%$.

Saran yang disampaikan terkait dengan hasil dan pembahasan adalah: perlu dilakukan penelitian lebih lanjut tentang penggunaan susu skim pada bakso jamur tiram untuk memperbaiki hedonik pada bakso jamur tiram. Kadar abu bakso jamur tiram putih agar sesuai dengan SNI bakso dilakukan dengan cara mengurangi jamur tiram.

\section{DAFTAR RUJUKAN}

Anwar, Y. 2012. Untung Menggunung dari Bisnis Olahan Jamur. Jakarta Selatan. PT Agromedia Pustaka.

Fitasari. E. 2009. Pengaruh Tingkat Penambahan Tepung Terigu Terhadap Kadar Air, Kadar Lemak, Kadar Protein, Mikrostruktur, dan Mutu Organoleptik Keju Gouda Olahan. Jurnal Ilmu dan Teknologi Hasil Ternak, 4(2): 17-29.

Pasaribu, D.T.Y. 2009. Pengaruh Taraf Penambahan Tepung Terigu sebagai Bahan Pengikat Terhadap Kualitas Sosis Daging Ayam. (Online), (http://repository.usu.ac.id/ handle/123456789/7615).

Sumarmi, 2006. Botani dan Tinjauan Gizi Jamur Tiram Putih. INNOFARM: Jurnal Inovasi Pertanian, 4 (2): 124-130. (Online) (https://,www.scribd.com/doc/25716 261/Botani-Dan-Tinjauan-GiziJamur-Tiram-Putih).

Widyastuti, N., Donowati, T., \& Reni, G. 2015. Potensi Beberapa Jamur Basidiomycota sebagai Penyedap Alternatif Masa Depan. Prosiding Seminar Agroindustri dan Lokakarya Nasional FKPT - TPI Program Studi TIP - UTM 